Долга Г.В.

\title{
АНТИКРИЗОВИЙ МЕНЕДЖМЕНТ ПІДПРИСМСТВ ТИМЧАСОВОГО РОЗМІЩЕННЯ БУКОВИНИ В УМОВАХ СОЦІАЛЬНО-ЕКОНОМІЧНОЇ НЕСТАБІЛЬНОСТІ
}

\begin{abstract}
У статті окреслено теоретичні засади антикризового менеджменту на підприємстві, а саме, досліджено сутність та особливості антикризового управління підприємств тимчасового розміщення Буковини в умовах соціально-економічної нестабільності. Охарактеризовано поняття та види стратегій антикризового управління. Проаналізовано стан діяльності підприємств тимчасового розміщення на Буковині. Внесені можливі пропозицї застосування антикризового менеджменту $з$ метою покращзення стану підприємств тимчасового розміщення Буковини.
\end{abstract}

Ключові слова: антикризовий менеджмент, підприємства тимчасового розміщення, сочіальноекономічна нестабільність,стратегія, криза, ризик, сфера туризму

Постановка проблеми. За сучасних умов переходу економіки України до ринкових відносин, прискореного науково-технічного прогресу, поглиблення глобалізаційних процесів, міжнародної інтеграції значно зростає тиск з боку зовнішнього середовища, загострюється конкурентна боротьба між підприємствами на споживчому ринку i, відповідно, зростає роль своєчасного та якісного аналізу конкурентоспроможності підприємств, формування ефективної маркетингової політики, а також удосконалення систем боротьби 3 кризовими явищами. Заклади тимчасового розміщення відіграють одну 3 передових ролей у розвитку сфери туризму та поліпшення економічної ситуації загалом. Це і актуалізує необхідність вивчення питання стану антикризового менеджменту вітчизняних підприємств та дослідження шляхів боротьби 3 кризовими явищами і станами.

Аналіз останніх досліджень і публікацій. Вивченням впливу кризових явищ на діяльність підприємств та дослідженням питання удосконалення антикризового менеджменту займалася велика кількість вітчизняних вчених, таких як: Д.А. Довгань, А.І. Дмитренко, А.А. Белясв, Е.М. Коротков, В.М. Рубан, 3.I. Тимошенко, Г.Б. Мунін, В.П. Дишлевий, В.В. Лихород та інші. Ці вчені зробили свій внесок у вивчення антикризового управління i його стратегій, та попри це, дане питання досі потребує глибокого аналізу у розрізі особливостей вітчизняного ринку.

Формулювання цілей статті. Метою дослідження $\epsilon$ аналіз особливостей функціо-

(C) Долга Галина Венедиктівна, к.е.н., доцент кафедри менеджменту i туризму Чернівецького торговельно-економічного інституту КНТЕУ, м.Чернівці, тел.: 0502615640, email: dolga.galina1985@gmail.com нування закладів тимчасового розміщення Буковини та визначення найефективніших шляхів удосконалення антикризового управління на цих підприємствах.

Опис основного матеріалу дослідження. Підприємницька діяльність тісно пов'язана 3 ризиками, особливо, враховуючи гучні події останніх років, нестабільну політичну та соціально-економічну ситуації, очевидно, що підприємства працюють в умовах невизначеності та підлягають впливу багатьох чинників, які здатні спричинити негативні тенденції в роботі організацій та навіть виникнення криз. Кризу в господарській діяльності найчастіше трактують як непередбачуваний переломний період функціонування організації, що виникає внаслідок погіршення одного або декількох параметрів підприємства та негативно відбивається на його діяльності і може навіть призвести до банкрутства. Серед факторів, що можуть спровокувати кризові явища на підприємстві, виокремлюють:

- зовнішні фактори. До них належать інфляція, економічна нестабільність, недосконалість законодавчої та податкової систем, посилення конкурентної боротьби на ринку, криза окремої галузі, політична нестабільність, соціальні розлади, непередбачувані екологічні обставини тощо;

- внутрішні фактори. До цієї категорії відносять відсутність чітко сформульованої стратегії функціонування підприємства, недосконала організаційна структура, нераціональне використання виробничих ресурсів, не налагоджена маркетингова політика, негативний стан корпоративної культури, відсутня чітка ієрархія, помилки в управлінні тощо.

Щодо визначення сутності антикризового управління Довгань Д.А. стверджує, що антикризове управління - ефективний 
менеджмент, який дає можливість вивести підприємство 3 кризи, сукупність заходів, спрямованих на досягнення чи відновлення платоспроможності, ліквідності, прибутковості і конкурентоспроможності підприємства і здатних привести підприємство до фінансового оздоровлення [1, с. 155]. Така точка зору $\epsilon$ вірною, проте розглядає поняття виключно 3 однієї сторони, залишаючи без уваги менеджмент, спрямований на попередження та запобігання дестабілізації. За визначенням Дмитренко А. I., антикризовий менеджмент - це сукупність керованих процесів, спрямованих на попередження та долання кризи підприємства, що відповідають цілям організації та об'єктивним тенденціям ii розвитку. Антикризове управління, як i будь-яка інша діяльність, є успішним, якщо при його здійсненні орієнтуються не на досягнення тимчасових ефектів, а на формування стійкого позитивного положення підприємства на ринку [2].

Якщо на підприємстві побудована ефективна система антикризового менеджменту, розлад можна не лише завчасно передбачити, а й управляти ним, або ж взагалі запобігти. 3 цією метою, доцільно здійснювати регулярний аналіз середовища функціонування даного підприємства, створювати прогнози різних сценаріїв розвитку подій та розробляти плани дій у випадку загострень протиріч у внутрішньому та зовнішньому середовищах організації [3].

Для того, щоб антикризовий менеджмент був дійсно ефективним, надзвичайно важливо дотримуватися програми антикризового управління, яка включає в себе, насамперед, розробку стратегії, ключових напрямів, принципів, методів та інструментів [4]. Стратегія антикризового управління підприємством сукупність дій i послідовність прийнятих управлінських рішень, що дозволяють оцінити, проаналізувати і виробити необхідну систему впливу на оздоровлення підприємства 3 метою запобігання його банкрутства або мінімізації наслідків кризи. Можна стверджувати, що в центрі антикризової стратегії управління може бути будь-яка мета: виживання, забезпечення (підтримка) конкурентоспроможності, задоволення потреби клієнтів, оптимальне використання своїх сильних сторін для досягнення переваг над конкурентами тощо [5,c.45]. Загальна стратегія підприємства поєднує систему взаємозалежних стратегій різного рівня: корпоративну; функціональну; операційну.

Найчастіше компанії використовують одну 3 чотирьох стратегій виходу компаній з кризи [6]: зміна позиціонування; перегляд портфеля бізнесів, концентрація на основній діяльності; інвестування в інновації; реорганізація.

Для швидкого виходу підприємства 3 кризи замало лише правильно підібраної стратегіі, куди важливіше значення має процес реалізації, в якому вагому роль відіграє контроль за результатами виконання плану, основними завданнями якого є визначення показників перевірки, порівняння досягнутих результатів із запланованими, у випадку появи відхилень 3'ясування причин їх виникнення та внесення коректив. Основним фактором, що може загальмувати процеси антикризового менеджменту, $€$ підвищення відповідальності менеджерів та ризиків при прийнятті рішень, тому особа, уповноважена на прийняття антикризових рішень, повинна володіти достатнім рівнем компетенції та гнучко реагувати на зміни зовнішнього середовища [7].

На сучасному етапі підприємницька діяльність Буковини знаходиться в незадовільному стані. Підприємства піддаються негативному впливу зовнішніх факторів, які дестабілізують їх функціонування. Така реакція найчастіше знаходить своє вираження у формі скорочення кількості підприємств приватного сектору, зниження обсягу виробництва та чисельності працюючих.

Так, за даними головного управління статистики у Чернівецькій області, якщо до 2014 року динаміка розвитку підприємств різних видів діяльності була позитивною, то станом на 2017 рік їх чисельність різко скоротилася (табл. 1)[8].

Проаналізувавши табл. 1, можна підсумувати, що кількісь підприємств за різними видами економічної діяльності почала зменшуватись 3 2015 року і становила 4065 один., що на 95 один., або 2,3\% менше, ніж у 2014 році. Цьому сприяла нестабільна політична ситуація в Україні. Стрімкий спад відбувся у 2017 році і кількість підприємств, у порівнянні 32016 роком, зменшилась на 13,7\% або на 554 одиниці.

У загальній кількості діючих підприємств у Чернівецькій області підприємства тимчасового розміщення займають 10 місце. За рахунок свого рекреаційного потенціалу та за умови побудови якісної туристичної інфраструктури Буковина має хороші перспективи розвитку туризму, важливою складовою якого є підприємства тимчасового розміщення. Підприємства тимчасового розміщення виконують доволі важливі функції в обслуговуванні туристів, а саме: забезпечення подорожуючих житлом, побутовими та додатковими послугами.

Будучи одним 3 найприбутковіших видів економічної діяльності, готельний бізнес створює робочі місця на ринку праці, а також є значущим засобом поповнення валютних запасів країни 
Таблиця 1

Кількість підприємств за видами економічної діяльності у Чернівецькій області, 2013-2017 рр. (одиниць)*

\begin{tabular}{|c|c|c|c|c|c|}
\hline \multirow[t]{2}{*}{ Підприємницька діяльність } & \multicolumn{5}{|c|}{ Роки } \\
\hline & 2013 & 2014 & 2015 & 2016 & 2017 \\
\hline Усього: & 3994 & 4160 & 4065 & 4054 & 3500 \\
\hline Сільське, лісове та рибне господарство & 729 & 749 & 713 & 741 & 705 \\
\hline Промисловість & 536 & 581 & 556 & 559 & 487 \\
\hline Будівництво & 379 & 383 & 367 & 354 & 271 \\
\hline $\begin{array}{l}\text { Оптова та роздрібна торгівля; ремонт автотранспортних } \\
\text { засобів і мотоциклів }\end{array}$ & 978 & 987 & 955 & 925 & 767 \\
\hline Тимчасове розміщення й організація харчування & 131 & 137 & 128 & 119 & 92 \\
\hline Інформація та телекомунікація & 148 & 151 & 151 & 155 & 133 \\
\hline Фінансова та страхова діяльність & 24 & 23 & 22 & 21 & 21 \\
\hline $\begin{array}{lccc}\text { Транспорт, сккладське } & \text { господарство, } & \text { поштова } & \text { та } \\
\text { кур'єрська діяльність } & & & \\
\end{array}$ & 173 & 177 & 177 & 179 & 161 \\
\hline Операції з нерухомим майном & 348 & 378 & 401 & 422 & 399 \\
\hline Професійна, наукова та технічна діяльність & 251 & 276 & 277 & 265 & 198 \\
\hline $\begin{array}{l}\text { Діяльність у сфері адміністративного та допоміжного } \\
\text { обслуговування }\end{array}$ & 159 & 172 & 171 & 160 & 134 \\
\hline Освіта & 22 & 26 & 25 & 24 & 22 \\
\hline Охорона здоров'я та надання соціальної допомоги & 52 & 54 & 54 & 61 & 56 \\
\hline Мистецтво, спорт, розваги та відпочинок & 15 & 14 & 17 & 18 & 14 \\
\hline Надання інших видів послуг & 49 & 52 & 51 & 51 & 40 \\
\hline
\end{tabular}

*Розраховано автором

Як свідчить головне управління статистики у Чернівецькій області, ринок підприємств готельного господарства $є$ досить нестабільним. Кількість підприємств тимчасового розміщення за період від 2015 по 2017 рік скоротилася на 12 одиниць, що становить $13,2 \%$ [8].

Щодо стану кількості зайнятих працівників на підприємствах тимчасового розміщення регіону, то кількість працівників поступово зменшується з 2013 року. У 2014 році кількість працюючих становила 1449 осіб, що на 7,8\% менше, ніж у 2013 році.

Різке зменшення кількості працюючих відбулося у 2016 році і становило 905 осіб, що на $34,8 \%$ менше, ніж у аналітичному 2015 році. Обсяги реалізованої продукції закладами тимчасового розміщення станом на 2017 рік становили 99927,5 тис грн., що на 12,6\% менше, ніж у 2016 році (114289,7 тис грн.) [10].

У 2015 році відбувся максимальний спад обсягу реалізованої продукції, який становив 84743,7 тис грн, що на $22,4 \%$ менше, ніж у 2014 році. Такий спад спричинила політична нестабільність в Україні та війна на Сході. У 2016 році відбулось збільшення обсягу реалізованої продукції, у порівнянні 32015 роком, на 29546 тис грн або на $34,8 \%$.

Але, у порівнянні з базисним 2016 роком, у 2017 році відбулося незначне зменшення обсягу реалізованої продукції підприємств тимчасового розміщення на $12,6 \%$. Ефективність діяльності підприємств наведено в таблиці 2 [12].

Таблиця 2 Фінансові результати до оподаткування підприємств тимчасового розміщення, 2013-2017 рр.*

\begin{tabular}{|l|c|c|c|c|c|}
\hline \multirow{2}{*}{} & \multicolumn{5}{|c|}{ Рік } \\
\cline { 2 - 6 } & 2013 & 2014 & 2015 & 2016 & 2017 \\
\hline Підприємства, які одержали прибуток & 3105,1 & 2966,5 & 1471,5 & 1951,7 & 2446,7 \\
\hline Підприємства, які одержали збиток & 4870,8 & 5269,9 & 9566,2 & 4202,5 & 14277,9 \\
\hline Фінансовий результат (сальдо) & $-1765,7$ & $-2303,4$ & $-8094,7$ & $-2250,8$ & $-11831,2$ \\
\hline
\end{tabular}

*Розраховано автором

На основі табл. 2 можна зробити висновок, що у 2017 році підприємства тимчасового розміщення зазнали максимального збитку, оскільки, фінансовий результат становить 11831,2 тис. грн. А мінімальний збиток був у 2013 році, оскільки, фінансовий результат становив $-1765,7$ тис. грн. Впродовж 2014-2016 років фінансове сальдо змінювалось поступово.

Насиченість регіону підприємствами тимчасового розміщення показано в таблиці 3 [10]. 
Таблиця 3

Насиченість Чернівецької області підприсмствами тимчасового розміщення

\begin{tabular}{|l|c|c|c|c|c|}
\hline Підприсмства тимчасового розміщення & $\mathbf{2 0 1 2}$ & $\mathbf{2 0 1 3}$ & $\mathbf{2 0 1 4}$ & $\mathbf{2 0 1 5}$ & $\mathbf{2 0 1 6}$ \\
\hline Чернівецька область & $\mathbf{8 0}$ & $\mathbf{8 7}$ & $\mathbf{9 1}$ & $\mathbf{8 7}$ & $\mathbf{7 9}$ \\
\hline міста & & & & & \\
\hline Чернівці & 30 & 34 & 35 & 33 & 29 \\
\hline Новодністровськ & - & 4 & 4 & 4 & 3 \\
\hline райони & & & & & \\
\hline Вижницький & 9 & 9 & 13 & 13 & 10 \\
\hline Герцаївський & 1 & 1 & - & - & - \\
\hline Глибоцький & 5 & 6 & 5 & 5 & 3 \\
\hline Заставнівський & - & - & - & - & - \\
\hline Кельменецький & 2 & 2 & 2 & 3 & 3 \\
\hline Кіцманський & 13 & 11 & 13 & 13 & 12 \\
\hline Новоселицький & 4 & 4 & 4 & 4 & 6 \\
\hline Путильський & 7 & 6 & 6 & 6 & 5 \\
\hline Сокирянський & 2 & 3 & 3 & 2 & 2 \\
\hline Сторожинецький & 4 & 4 & 3 & 2 & 2 \\
\hline Хотинський & 3 & 3 & 3 & 2 & 4 \\
\hline
\end{tabular}

Проаналізувавши табл.3, можна зробити висновок, що найбільша кількість підприємств тимчасового розміщення зосереджена в м. Чернівці, і станом на 2017 рік становить 29 одиниць. Також велика кількість підприємств розміщена у Кіцманському (12 одиниць) та Вижницькому (10 одиниць) районах.

Зовсім відсутні підприємства тимчасового розміщення у Герцаївському та Заставнівському районах [10].

Щодо структури підприємств тимчасового розміщення можна зробити висновок, що найбільшу частку займають готелі - 83\%; туристські бази, гірські притулки, студентські літні табори та інші місця для тимчасового розміщення - $14 \%$, а найменшу частку займають мотелі - 3\% [9, с.54].

Згідно даних головного управління статистики у Чернівецькій області за оцінкою туристів можна виділити три найкращих підприємства тимчасового розміщення. Перше місце займає готель «AllureInn», що знаходиться у м. Чернівці, за адресою: Центральна площа, 6. Серед переваг даного закладу тимчасового розміщення найбільш вагомими $\epsilon$ місце розташування - готель розташований в самому центрі міста, тому основні визначні пам'ятки в пішій доступності, рівень обслуговування, кваліфікація персоналу, стиль готелю, власний ресторан, оснащення - даний готель відповідає стандартам 4*. Серед мінусів - відсутність власної парковки. На другому місці, за оцінкою туристів, знаходиться готельний комплекс «Буковина». Готель знаходиться по вул. Головній, 141. Його перевагами є близькість до центру міста, парку ім. Т.Г.Шевченка та стадіону «Буковина». Готельний комплекс має два ресторани, які працюють цілодобово. Висококваліфікований персонал, високий рівень обслуговування, велика територія для паркінгу та відповідає категорії 4*. Мінуси - номери, які виходять на вул. Головну, недостатньо шумоізольовані. Третє місце займає готель «Преміум». Готель має $3^{*}$, розташований в центрі міста на вул. Головна, 124 б, в 20 хв. від центральної вулиці. Висококваліфікований та привітний персонал, обслуговування на високому рівні. На території є ресторан та власна парковка. Мінуси - недостатня шумоізоляція номерів.

Отже, проаналізувавши економічні показники діяльності підприємств тимчасового розміщення в Чернівецькі області за 2013-2017 pp., можна зробити висновок про зменшення прибутку, обсягів реалізованих продуктів, кількості реалізованих туристичних послуг та кількості підприємств тимчасового розміщення загалом.

Стан готельного господарства на сьогоднішній день знаходиться в незадовільному стані. Це зумовлено наступними причинами [14, с.241]: недоліки законодавства у сфері інвестування та підприємництва; невідповідність податкової та бухгалтерської систем міжнародним стандартам; відсутність потужної страхової системи, яка б покривала комерційні ризики під час реалізації інвестиційних проектів; нестабільність політичної ситуації в Україні; війна на сході України; відсутність стійкого попиту на вітчизняні готельні послуги; інфраструктура готельних підприємств не відповідає міжнародним стандартам; низька кількість закладів високої категорії; застаріла матеріально-технічна база готелів; відсутність чіткого законодавчого визначення ролі 
готельного господарства в туристичній сфері та на ринку послуг; низька якість надаваних послуг та культура обслуговування клієнтів; низький рівень купівельної спроможності населення; поганий стан доріг; нестабільність національної валюти тощо.

Важливою умовою розвитку туризму на Буковині $\epsilon$ якісний рівень готельного господарства. Регіон має хороші перспективи розвитку туризму i, відповідно, готельного господарства, завдяки зручному географічному розташуванню та великій кількості туристичних ресурсів. Розвиток та вдосконалення малих та середніх підприємств тимчасового розміщення сприятиме розвитку туристської інфраструктури, розвитку туризму, збільшенню робочих місць.

На сьогоднішній день українські заклади тимчасового розміщення, особливо це стосується провінційних міст, не мають стійких конкурентних позицій на міжнародному ринку. Адже ні інфраструктура закладів розміщення, ні рівень сервісу та спеціалізація не відповідають міжнародним нормам проживання та відпочинку.

Частину недоліків, таких як податкова, законодавча, інвестиційна політика, соціальна та економічна нестабільність неможливо вирішити без участі державних органів. Ринок підприємств розміщення потребує змін та вдосконалень вже існуючих послуг 3 обов'язковою підтримкою держави в таких напрямах [15]:

• удосконалення нормативно-законодавчої бази підприємств галузі;

• налагодження потужної

вітчизняного туристичного продукту;

- надання різноманітних туристичних продуктів у співвідношенні ціна та якість;

- подальший розвиток інтернет-комерції та соціальних медіа;

- впровадження сучасних інформаційних технологій, Internet і мобільних додатків;

- покращення якості готельного продукту та сервісу стосовно індивідуальних потреб клієнтів;

- запровадження в туристичній галузі програми КСО та іiі основних принципів: відкритості, прозорості;

- залучення вітчизняних та іноземних інвесторів, кредитних коштів для будівництва нових та модернізації вже діючих туристичних об'єктів;

- впровадження високих стандартів обслуговування вітчизняної сфери гостинності.

Проте питання кваліфікації працівників, якості обслуговування, стану матеріальнотехнічної бази, споживчої лояльності та загального іміджу підприємств, які знаходяться в незадовільному стані, є локальними явищами, які необхідно вдосконалювати та розвивати.

На нашу думку, в ситуації, що склалася, на сьогоднішній день найдоречніше використати стратегію позиціонування в комплексі 3 постійним вдосконаленням якості послуг. Даний напрямок антикризових заходів допоможе розвіяти стереотипне мислення про місцеві підприємства тимчасового розміщення як про низько кваліфіковані заклади з поганим рівнем обслуговування, дозволить підвищити їх конкурентоспроможність та здобути довіру споживачів.

Позиціонування готельного продукту - це процес пошуку такої ринкової позиції для готельного продукту, яка буде вигідно вирізняти його 3-поміж положення конкурентів. Залежно від того, на яку категорію покупців він розрахований, формуються вимоги до якості, дизайну, ціни та ін., тобто визначається позиція готельного продукту на вибраному сегменті готельного ринку. Головне завдання позиціонування в готельному бізнесі полягає в комплексі зусиль, спрямованих на адаптацію готельних продуктів до вимог цільових сегментів індустрії готельного бізнесу, з налагодженням його від основних конкурентів за рахунок унікальних характеристик готельних продуктів або порядку та умов придбання їх. Стратегія позиціонування призначена для виграшу за рахунок підвищення ефективності маркетингових зусиль. Заклад зобов'язаний ідентифікувати найбільш значущі характеристики або користь, які, напевно, повинні виявитися виграшними для тієї або іншої марки і завоювати свідомість споживачів [13, с.155].

Доречними кроками у цій ситуації ми вбачаємо створення базової моделі гостинності та жорсткого стандарту обслуговування, чітке окреслення вимог до роботи персоналу та моніторинг їх виконання. Адміністрації закладів необхідно чітко окреслити трудові стандарти підприємств, а саме: сервісу; етикету; зовнішнього вигляду; корпоративної етики.

Дотримання стандартів сервісу забезпечують якісне надання послуг споживачам. Працівники закладу повинні мати вищу освіту та володіти відповідними знаннями в даній сфері, знати та дотримуватися правил внутрішнього розпорядку готелю, професійно виконувати поставлені задачі та робити все можливе для забезпечення комфорту споживачів. Стандарти етикету передбачають дотримання персоналом правил поведінки, правильне та толерантне ведення розмов, ввічливе та доброзичливе ставлення до осіб, що проживають та споживають додаткові послуги в закладах тимчасового розміщення. 
Стандарти зовнішнього вигляду окреслюють, який зовнішній вигляд $\epsilon$ прийнятним для працівників даного закладу, передбачають використання уніформи, доречний макіяж, чистоту та охайність персоналу. Під стандартами корпоративної етики розуміють взаємовідносини працівників між собою, підпорядкування працівників та використання єдиних правил поведінки всією організаційною структурою.

3 метою покращення кваліфікації персоналу закладів потрібно влаштовувати тренінги, знаходити чи організовувати курси для підвищення кваліфікації, різні навчальні проекти, робити все необхідне для того, щоб персонал закладу володів всіма знаннями та тонкощами готельної справи.

Висновки i перспективи подальших досліджень. Ефективність функціонування будьякого підприємства залежить від тієї репутації, яка склалася у свідомості суспільства. На іiі основі у потенційних відвідувачів формується уявлення про якість послуг, а як відомо, за високу якість, оригінальні послуги та хорошу репутацію споживач готовий платити більше. Використовуючи бренд, людина відчуває власну статусність та важливість, він визначає довіру споживача до певного підприємства та готовність користуватися послугами підприємства незалежно від цінової пропозиції менш іменитих конкурентів. Таким чином, перед менеджментом підприємств тимчасового розміщення стоїть завдання відкорегувати діяльність підприємств до такої міри, поки в споживачів не буде чіткої думки про те, що в місцевих закладах працюють висококваліфіковані працівники, які надають лише якісні послуги на високому професійному рівні.

Потребують подальшого розвитку дослідження державної політики в сфері готельного господарства, де на першому місці сьогодні має стати розробка й реалізація адекватних заходів 3 підвищення якості обслуговування, сприяння відновленню туристичних потоків, а також покращення іміджу країни на міжнародній арені.

\section{ПЕРЕЛІК ВИКОРИСТАНИХ ДЖЕРЕЛ}

1. Довгань Д. А. Антикризове управління як спосіб запобігання та попередження неплатоспроможності корпорації / Д. А. Довгань // Вісник Чернівецького торговельно-економічного інституту. - 2013. - Вип. 3. Економічні науки. - С. 152-156.

2. Дмитренко А. І. Стратегії антикризової діяльності промислових підприємств [Електронний ресурс] / А. І. Дмитренко // Вісник Криворізького економічного інституту КНЕУ. - 2009. - №4. - (20). - Режим доступу: http://www.kneu.dp.ua

3. Антикризове управління [Електронний ресурс] // Офіційний сайт «Bigenergy». - Режим доступу: http://bigenergy.com.ua

4. Антикризове управління підприємством // Бібліотека економіста [Електронний ресурс]. - Режим доступу: http://library.if.ua/book/6/668.html

5. Беляев А. А. Антикризисное управление : учебник. 2-е издание / А. А. Беляев, Э. М. Коротков. - М. : Юнити, 2009. - 312 с.

6. Десять прикладів виходу підприємства 3 кризи [Електронний ресурс]. - Режим доступу: https://alltop10.org

7. Рубан В. М. Типи і види стратегій в антикризовому управлінні. Тактики антикризового управління [Електронний ресурс] / В. М. Рубан // Науковий вісник Херсонського державного університету. - 2014. - №7. Режим доступу: http://www.ej.kherson.ua

8. Кількість підприємств за їх розмірами за видами економічної діяльності [Електронний ресурс] / Головне управління статистики у Чернівецькій області. - Режим доступу : http://www.cv.ukrstat.gov.ua

9. Туризм та відпочинок в області : статистичний збірник. - Чернівці : Головне управління статистики у Чернівецькій області, 2017. - 88 с.

10. Кількість зайнятих працівників на підприємствах за їх розмірами за видами економічної діяльності [Електронний ресурс] / Головне управління статистики у Чернівецькій області. - Режим доступу: http://www.cv.ukrstat.gov.ua

11. Обсяг реалізованої продукції (товарів, послуг) підприємств за їх розмірами за видами економічної діяльності [Електронний ресурс] / Головне управління статистики у Чернівецькій області. - Режим доступу: http://www.cv.ukrstat.gov.ua

12. Фінансові результати до оподаткування підприємств за їх розмірами за видами економічної діяльності [Електронний ресурс] / Головне управління статистики у Чернівецькій області. — Режим доступу: http://www.cv.ukrstat.gov.ua

13. Котенко Р. М. Сучасний стан розвитку готельного господарства України [Електронний ресурс] / Р. М. Котенко // Індустрія гостинності у країнах Європи: Матеріали III міжнародної науково-практичної конференції, м. Сімферополь, 4-6 грудня 2009 р. - Сімферополь : ВіТроПринт, 2009. - С. 153-159. - Режим доступу: https://refdb.ru/look/2415555.html 
14. Рахман М. С. Кон'юктурний аналіз розвитку готельної індустрії як складової туризму України / М. С. Рахман // БІЗНЕСІНФОРМ.- 2015. - №11. - С. 454.

15. Тимошенко 3. І. Позиціонування готельного продукту / 3. І. Тимошенко, Г. Б. Мунін, В. П. Дишлевий // Маркетинг готельно-ресторанного бізнесу [Електронний ресурс]. - Режим доступу : http://tourismbook.com/pbooks/book-37/ua/chapter-1851/

\section{REFERENCES}

1. Dovhan', D.A. (2013). Antykryzove upravlinnia iak sposib zapobihannia ta poperedzhennia neplatospromozhnosti korporatsii [Anti-crisis management as a way to prevent and prevent insolvency of the corporation]. Visnyk Chernivets'koho torhovel'no-ekonomichnoho instytutu - Bulletin of the Chernivtsi Trade and Economic Institute, 3, 152156 [in Ukrainian].

2. Dmytrenko, A.I. (2009). Stratehii antykryzovoi diial'nosti promyslovykh pidpryiemstv [Strategies of Anti-crisis activity of industrial enterprises]. Visnyk Kryvoriz'koho ekonomichnoho instytutu KNEU - Bulletin of the Kryvy Rih Economic Institute of KNEU, 4 (20). Retrieved from: http://www.kneu.dp.ua [in Ukrainian].

3. Antykryzove upravlinnia [Anticrisis management]. bigenergy.com.ua. Retrieved from: http://bigenergy.com.ua [in Ukrainian].

4. Antykryzove upravlinnia pidpryiemstvom [Anticrisis management of the enterprise]. library.if.ua. Retrieved from: http://library.if.ua/book/6/668.html [in Ukrainian].

5. Beliaev, A.A. \& Korotkov, E.M. (2009). Antykryzysnoe upravlenye [Anti-crisis management]. 2nd edition. Moscow : Unity [in Russian].

6. Desiat' prykladiv vykhodu pidpryiemstva z kryzy [Ten examples of exit from a crisis]. alltop10.org. Retrieved from: https://alltop10.org [in Ukrainian].

7. Ruban, V.M. (2014). Typy i vydy stratehij $\mathrm{v}$ antykryzovomu upravlinni. Taktyky antykryzovoho upravlinnia [Types and types of strategies in crisis management. Tactics of Crisis Management]. Naukovyj visnyk Khersons'koho derzhavnoho universytetu - Scientific Bulletin of Kherson State University, 7. Retrieved from: http://www.ej.kherson.ua [in Ukrainian].

8. Kil'kist' pidpryiemstv za ikh rozmiramy za vydamy ekonomichnoi diial'nosti [Number of enterprises by size by type of economic activity]. Main Department of Statistics in Chernivtsi region. cv.ukrstat.gov.ua Retrieved from: http://www.cv.ukrstat.gov.ua [in Ukrainian].

9. Turyzm ta vidpochynok v oblasti [Tourism and recreation in the region]. (2017). Chernivtsi, Holovne upravlinnia statystyky u Chernivets'kij oblasti [in Ukrainian].

10. Kil'kist' zajniatykh pratsivnykiv na pidpryiemstvakh za ikh rozmiramy za vydamy ekonomichnoi diial'nosti [Number of employed workers at enterprises by size by type of economic activity]. cv.ukrstat.gov.ua. Retrieved from: http://www.cv.ukrstat.gov.ua [in Ukrainian].

11. Obsiah realizovanoi produktsii (tovariv, posluh) pidpryiemstv za ikh rozmiramy za vydamy ekonomichnoi diial'nosti [Volume of sold products (goods, services) of enterprises by their size by type of economic activity]. Main Department of Statistics in Chernivtsi region. cv.ukrstat.gov.ua. Retrieved from: http://www.cv.ukrstat.gov.ua [in Ukrainian].

12. Finansovi rezul'taty do opodatkuvannia pidpryiemstv za ikh rozmiramy za vydamy ekonomichnoi diial'nosti [Financial results before taxation of enterprises by their size by type of economic activity]. Main department of statistics in Chernivtsi region. cv.ukrstat.gov.ua. Retrieved from: http://www.cv.ukrstat.gov.ua [in Ukrainian].

13. Kotenko, R.M. (2009). Suchasnyj stan rozvytku hotel'noho hospodarstva Ukrainy [The current state of the hotel economy development in Ukraine]. Materialy III mizhnarodnoi naukovo-praktychnoi konferentsii «Industriia hostynnosti u krainakh Yevropy» - Materials of the 3rd international scientific and practical conference «Hospitality industry in Europe». (pp. 153-159). Simferopol: VTropPrint. Retrieved from: https://refdb.ru/look/2415555.html [in Ukrainian].

14. Rakhman, M.S. (2015). Kon'iukturnyj analiz rozvytku hotel'noi industrii iak skladovoi turyzmu Ukrainy [Conjunctural analysis of the development of the hotel industry as a component of Ukrainian tourism]. BIZNESINFORM-BIZNESINFORM, 11, 454 [in Ukrainian].

15. Tymoshenko, Z.I., Munin, G.B. \& Dyshlevyi, V.P. Pozytsionuvannia hotel'noho produktu [Positioning of the hotel product]. Marketynh hotel'no-restorannoho biznesu - Marketing of hotel and restaurant business. Retrieved from: http://tourism-book.com/pbooks/book-37/en/chapter-1851/ [in Ukrainian].

Одержано 09.03.2018 p. 